\title{
WORK MEASUREMENT STUDY ON MOTOR-MANUAL PINE TAPPING OPERATION: THE APPLICATION OF THE CONCEPT OF LEAN MANUFACTURING AND ALLOWANCES
}

\author{
Efi Yuliati Yovi*, Diah Prasetiana, and Natasha Aquilla Nirmalasari \\ Department of Forest Management, Faculty of Forestry and Environment, IPB University, \\ Jl. Raya Dramaga, Campus IPB Dramaga Bogor, 16680 West Java, Indonesia
}

Received: 11 January 2021 Revised: 21 April 2021 Accepted: 22 April 2021

\begin{abstract}
WORK MEASUREMENT STUDY ON MOTOR-MANUAL PINE TAPPING OPERATION: THE APPLICATION OF THE CONCEPT OF LEAN MANUFACTURING AND ALLOWANCES. Derivated products of pine resin have been recognised as competitive commodities in global trade, increasing the need to use resources more efficiently. A hand-held tapping machine with small hoe-shape cutters called "mujitek" has been widely applied in Indonesia among efforts to answer this challenge. In this study, a series of observed (actual) work time data were measured and analysed, adopting lean manufacturing to calculate the basic and standard time of the work and estimate the work produced on the tapping operation. Work elements were identified based on their contribution to change or transform the product and were categorised as value-added, non-value-added, and special allowance. Quantitative data on the work productivity in the tapping operation can be used as one fundamental data in determining a work plan to establish a continuous improvement process. The variable fatigue allowances taken into account in this study were standing posture, abnormal posture, muscular energy, atmospheric conditions, and noise. This study shows that non-value-added work elements (repairing machines, chatting, and smoking) cause inefficiency in tapping operation. Analysis of added-value work elements proved that this hand-held tapping machine offers a higher $(1.7$ times) work productivity than conventional hand-held tapping tools. However, since humans have limitations in the physical, physiological, and mental dimensions that limit their ability to carry out work at a certain level, the discovered work productivity level should also be validated with other thresholds, e.g., physical workload and risk perception.
\end{abstract}

Keywords: Ergonomics, pine resin, time work, standard time, work productivity

PENGUKURAN KERJA PADA OPERASI PENYADAPAN GETAH PINUS SECARA MOTORMANUAL: APLIKASI KONSEP LEAN MANUFACTURING DAN KELONGGARAN. Produk turunan getah pinus telah diakui sebagai komoditas yang kompetitif dalam perdagangan global, hal ini mendorong peningkatan efisiensi penggunaan sumber daya. Salah satu upaya yang dilakukan untuk menjawab tantangan tersebut adalah penggunaan secara luas mesin sadap dengan pemotong berbentuk cangkul kecil yang disebut "mujitek.". Dalam penelitian ini, serangkaian data waktu kerja yang diamati (waktu kerja aktual) diukur dan dianalisis dengan mengadopsi konsep lean manufacturing untuk menghitung waktu dasar dan waktu standar dan menentukan produktivitas kerja penyadapan. Elemen kerja diidentifikasi berdasarkan kontribusinya dalam proses mengubah atau mentransformasikan produk, dan dikategorikan sebagai elemen kerja dengan nilai tambah, non-nilai tambah, dan kelonggaran khusus. Data kuantitatif produktivitas kerja pada operasi penyadapan dapat digunakan sebagai salah satu data dasar dalam menentukan rencana kerja untuk melangsungkan proses perbaikan yang berkelanjutan. Variabel kelonggaran kelelahan yang diperbitungkan dalam penelitian ini adalab postur berdiri, postur abnormal, energi yang dikeluarkan, kondisi atmosfir, dan kebisingan. Studi ini menunjukkan babwa elemen pekerjaan yang tidak memiliki nilai tambah (memperbaiki mesin, mengobrol, dan merokok) menyebabkan ketidakefisienan dalam kegiatan penyadapan. Analisis terbadap elemen kerja bernilai tambah membuktikan bahwa penggunaan mesin sadap genggam menawarkan produktivitas kerja yang lebih tinggi (1,7 kali lipat) dibandingkan dengan alat sadap genggam konvensional. Namun, karena manusia memiliki keterbatasan dalam dimensi fisik, fisiologis, dan mental yang membatasi kemampuannya untuk melaksanakan pekerjaan pada tingkat tertentu, maka tingkat produktivitas kerja yang ditemukan juga harus divalidasi dengan ambang batas lainnya, antara lain beban kerja fisik dan persepsi terbadap risiko.

Kata kunci: Ergonomi, getah pinus, penelitian waktu, waktu standar, produktivitas kerja

*Corresponding author: eyyovi@apps.ipb.ac.id 


\section{INTRODUCTION}

Pinus (Pinus merkusii Jungh et de Vries) is a native Indonesian species. Pine yields resin (its subsequent productions are gum turpentine and gum rosin/gum naval stores). Indonesia has managed pine on a large scale; the estimated plantation area is 1.8 million ha, $882,066.53$ ha area located in Java Island (Perhutani, 2020). The national export value of this non-timber forest product was recorded at USD 84.7 million in 2019 (TrendEconomy, 2019), far greater than the economic value of pinewood obtained in the same year (BPS, 2020).

Pine tapping activity provides significant employment opportunities for local communities (Yovi \& Amanda, 2019). In Indonesia, pine resin tapping is carried out under manual or motor-manual operation. Conventional tapping tool in the form of a small iron-made hoe (kadukul) (Sundanese) (pethel) (Javanese) to chop the bark away (tapping face) in Hugue or square (koakan) tapping technique (Yovi \& Amanda, 2019) is the most common tapping practice. However, in the last decades, the use of a hand-held tapping machine, local people call it "mujitek", has received wide attention. This tool was invented in 2012 by Muji, a pine tapper from Malang Forest District, Indonesia. He constructed mujitek from a lawnmower with a modification to the cutting head. Compared to the conventional tapping tool, this tapping machine offers convenience in completing the work, especially in the context of working speed.

In Java Island, almost all pine forests are managed by the state-owned company Perum Perhutani. The pine tapping activities are carried out by local communities who hold a "tapping contract" with a piece-rate payment system, where the wages are paid based on the volume of the tapped resin (Yovi \& Amanda, 2019). This payment system is common among low-wage industries and widely adopted in developing countries (Davis, 2016). This payment system may offer higher earnings than the fixed-rate payment system (Hart, 2016). However, this payment system may drive workers to pursue higher production (Borino, 2018) and give less attention to their occupational safety and health. The more resin collected, the greater the wages that can be received. The same thing is valid for the company; the more resin is harvested, the greater the profit.

This system leads on how to design the work to fit the tapping operation that benefits both workers and the plantation company. Among the many questions pointed out to the humanmachine performance compared to motormanual tapping, productivity is crucial. The information on work productivity will help both the tapper and the company determine a work plan to establish a continuous improvement process (Womack \& Jones, 2003).

Measuring work productivity is very difficult, especially when the work involves the presence of human activity. Therefore, considering humans' limitations, it is important to measure work productivity by using work and time study techniques that accommodate humans' physical, physiological, and mental constraints. In answering these requirements, a lean manufacturing concern (Mayer, Maciel, Baggio, \& Siendenberg, 2015) is apt to be applied in time study analysis (Cury \& Saraiva, 2018).

Up to now, no work and time study analysis in motor-manual pine tapping operation had been carried out under the lean manufacturing concept. Therefore, this research was aimed to measure work productivity in motormanual tapping operation, and at the same time, demonstrate how the lean manufacturing concept (that repositioning added-value and non-added-value work elements) is applied to estimate the standard time. The time study analysis described in this study would enrich the time study analysis techniques in measuring the standard work productivity, especially in examining human-work relations in the forestry sector. 


\section{MATERIAL AND METHOD}

Tapping operation consists of wounding/ refreshing and collecting. In this study, the time study analysis was carried out for wounding activities. Primary data taken includes observed time and daily temperature at the workplace. The tools used in data retrieval and processing were a video camera and a WBGT meter. The study was conducted from February to March 2020 in 3 tapping sites of $P$. merkusii Jungh et de Vries (aged 19 years). The understorey conditions at the study sites were relatively similar, with slightly thicker shrubs in some locations. The slope class is $6-15 \%$, with an average temperature of $30^{\circ} \mathrm{C}$. Work productivity is defined as the ratio between the output to the input of a production process. In this study, work productivity refers to labour productivity that describes the ratio between tapped trees to the used capacity (given in time units).

Observations were made on three respondents. In total, they tapped 405 trees per day. There were three days of observations for each respondent. For the comprehensive application of the lean manufacturing concept, one working day is considered one work cycle in this analysis. Observation time was measured by recording the tapping activities of the whole day using a video camera. Before data collection, socialisation and habituation were carried out to avoid overacting that may arise due to awkward feelings when observed using a video camera all day long.

\section{A. Determining Work Elements}

The work elements determination in this study adopts the "lean manufacturing" principle proposed by Mayer, Maciel, Baggio, and Siendenberg (2015):

"The work can be divided into work that adds value and work that does not add value. The work that does not add value can be considered a waste. On the other hand, work that adds value is the one that involves processing to change or transform the product or the assembly thereof. It should also be considered that work that does not add value can be necessary due to the machines and processes' characteristics." Mayer et al.
(2015) stated that one cycle of work may consist of several value-added work elements and nonvalue-added work elements. This opinion was later adopted by Cury and Saraiva (2018).

The value-added work elements are defined as all work elements needed for the whole cycle to take place. Value-added work elements are further classified as effective and supportive work elements. An effective work element is a work element that directly contributes to the cycle, therefore, standard work time is calculated only for this effective work element. The supportive work elements are defined as all work elements that do not directly contribute to the work cycle but are still necessary to run the whole process. This supportive work element is unintentional/unavoidable. In general, these work elements can be classified as operative and mechanical supportive work elements. These work elements needed to be minimised.

Non-value-added work elements are work elements that do not support and are not directly or indirectly related to the production process. Apart from being unrelated to the production process, this element's main characteristic increase production costs, avoidable time delays, and unimportant. In the concept of "lean manufacturing," this work element needs to be eliminated. Mayer et al. (2015) categorised it as "waste" - so that the standard time for these non-value-added work elements is not necessary. This "waste" is generally classified as a personal and mechanical interruption.

In a work cycle, there is another unavoidable delay that applies to work elements. This delay is categorised as a special allowance that plays a role as an enabling element. This allowance is directly added to the cumulative standard time of effective and supportive work elements in a standard time calculation. A detailed work element classification is shown in Figure 1.

\section{B. Standard Time Measurement}

Several terminologies used in this time study analysis, i.e., observed time, basic time, normal time, standard time, and allowances, are described as follows: 


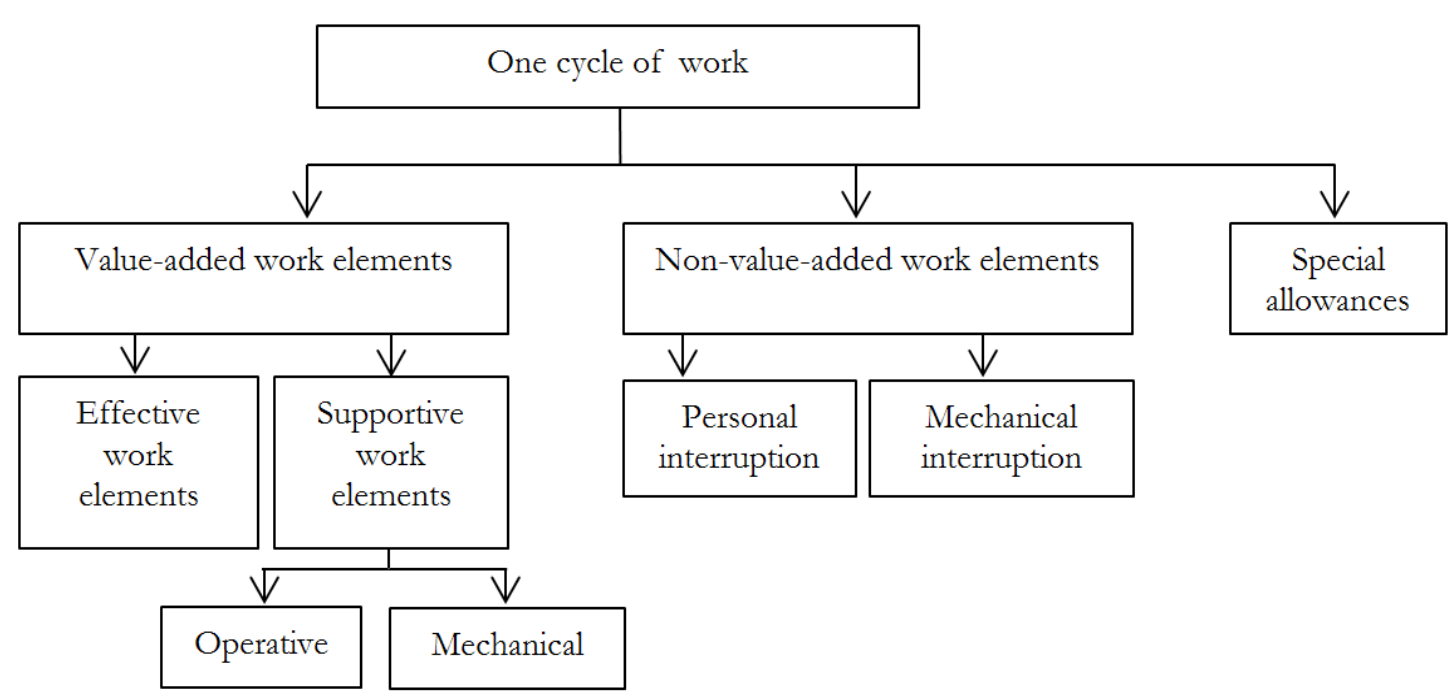

Figure 1. Work elements classification based on the lean manufacturing concept

\section{Observed time}

The actual work time obtained as a result of observations is referred to as "observed time."

\section{Basic time (normal time)}

Basic time is obtained by multiplying the observed time to the respondent's performance rating (known as a performance rating factor, $\mathrm{RF}$ ) (Equation 1). RF is defined as the ratio between the operator's actual performance to the normal performance (refers to workers with standard pace). Standard pace is defined as the effective rate of performance of a conscientious, self-paced, qualified employee when working neither fast nor slow and giving due consideration to the specific job's physical, mental, or visual requirements (Niebel \& Freivalds, 2003). RF value could be determined through preliminary observations, assessment of the co-workers, or using a predetermined value. The RF value is used as a correction factor to determine the basic time value from observation time (Equation 1).

$\mathrm{BT}_{\mathrm{we}-\mathrm{i}}=\mathrm{OT}_{\mathrm{we}-\mathrm{i}} \times \mathrm{RF}$

Remarks:

$\mathrm{BT}_{\text {we }}=$ Basic time for work element-i

$\mathrm{OT}_{\text {we-i }}=$ Observed time for work element-i

$\mathrm{RF}^{\text {we-i }} \quad$ Rating factor for work element-i

\section{Allowances}

Allowance is an addition to basic time, allocated and valued proportionally based on the workers' internal and external conditions. Allowances accommodate the humans' limitations in physical, physiological, and mental aspects. The allowance distribution in this study adopts Niebel's method (Niebel \& Freivalds, 2003). In this study, the allowance structure was categorised into constant and variable fatigue allowances.

Constant allowances consist of personal needs and basic fatigue allowances. The first constant allowance refers to all cessation in work taken to maintain the workers' general well-being. Including in this category are personal delays for drinking water and going to the restroom. According to globally adopted consensus, a value of 5\% for personal allowance and 4\% for basic fatigue allowance are considered adequate (ILO, 1979).

The second allowance is defined as the delay required to compensate for the energy expended to carry out the work (Niebel \& Freivalds, 2003), which may vary depending on the process, equipment, and materials. The common variable fatigue allowances are (but not limited to) standing, abnormal posture, 
use of force, illumination level, visual strain, atmospheric condition, close attention, noise level, mental strain, monotony, and tediousness. In this study, the variable fatigue allowances used were only needed according to the tapping work characteristics, identified as standing, abnormal posture, use of force energy, atmospheric conditions, and noise. Constant and variable fatigue allowances applied in this study, determined by several previous studies and widely adopted, are tabulated in Table 1 .

\section{Standard time}

Standard time is required for a qualified worker to perform the work at a standard pace and exert average effort (Niebel \& Freivalds, 2003). It means that the standard time for a work element is a function of both basic time and allowance factors. Standard time is measured

Table 1. Constant and variable rest allowances applied in this study, its equation, and references

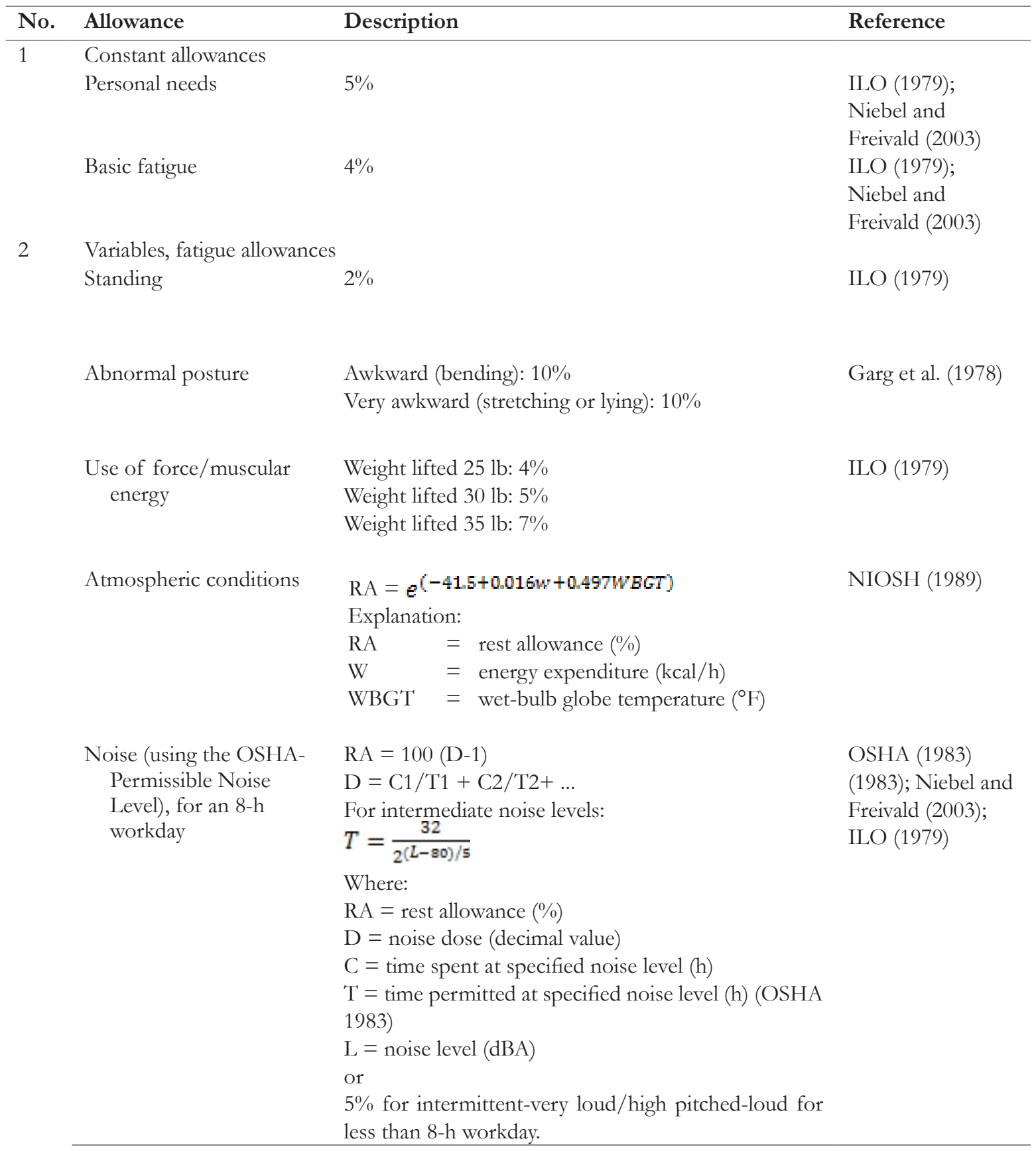




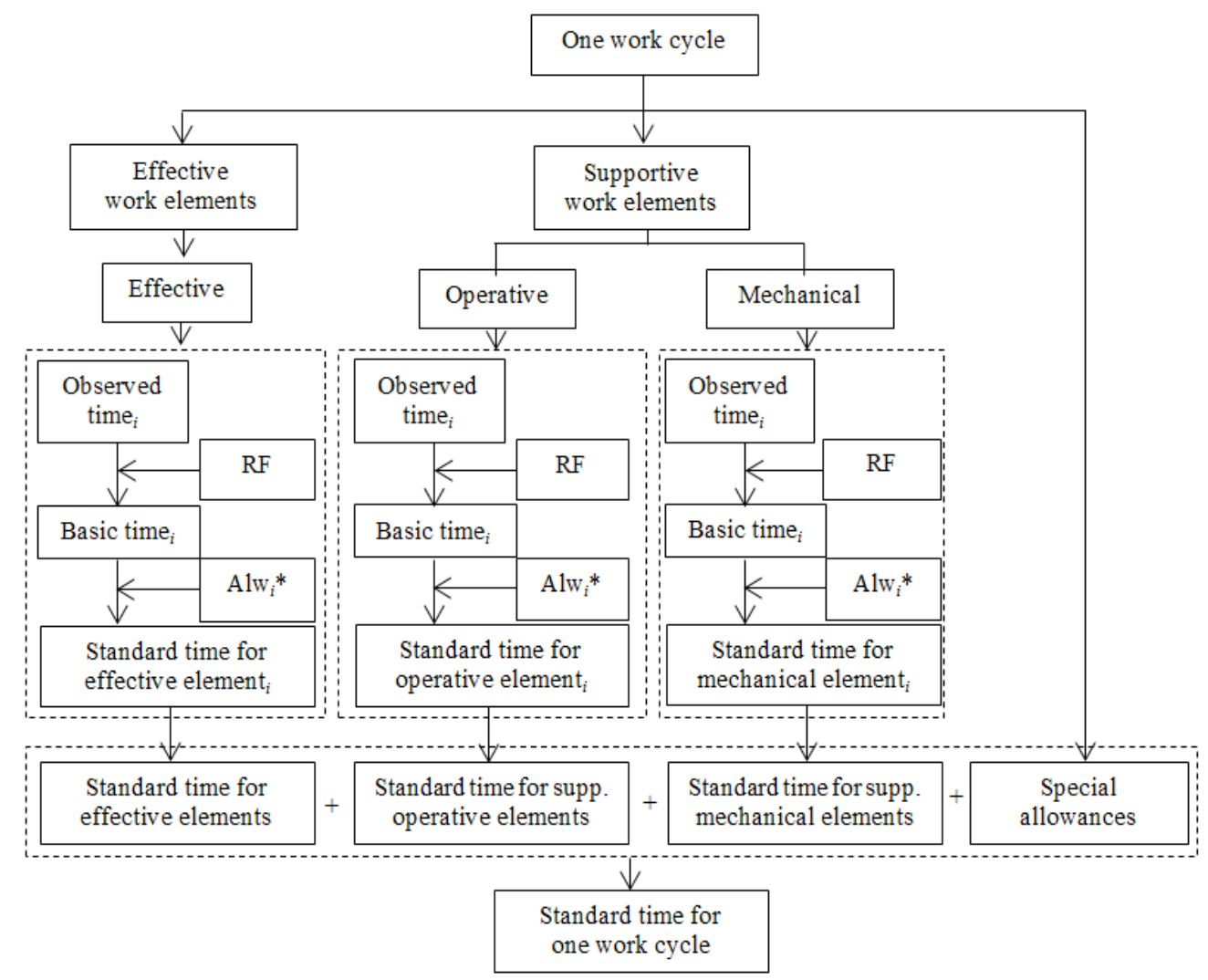

Figure 2. The workflow on standard time measurement

Remarks: $\mathrm{RF}=$ Rating Factor; $\mathrm{Alw}_{\mathrm{i}}=$ allowance for work element

only for value-added work elements. In one work cycle, the standard time is calculated as the sum of elemental's standard time (Equation 2 ), in which the standard elemental time is calculated by multiplying the elemental's basic time by (total) allowance multiplier (Equation 3 ). Thus, if $20 \%$ of allowances are provided on an operation, the multiplier is equal to 1.2. The flow of standard time estimation activities in one work cycle are described in Figure 2.

$\mathrm{ST}_{\text {cycle }}=\sum_{i=1}^{n} S T_{\text {we-i }}$

Remarks:

$\mathrm{ST}_{\text {cycle }}=$ Standard time for one cycle with $\mathrm{n}$ valueadded work elements

Where:

$\mathrm{ST}_{\mathrm{we}-\mathrm{i}}=\mathrm{BT}_{\mathrm{we}-\mathrm{i}}\left(1+\mathrm{Al}_{\mathrm{we}-\mathrm{i}}\right)$

Remarks:

$\mathrm{ST}_{\mathrm{we}, \mathrm{i}} \quad=$ Standard time for work element-i

$\mathrm{BT}_{\text {we-i }}=$ Basic time for work element-i

$\mathrm{Al}_{\text {we-i }} \quad=$ Allowance for work element-i

\section{RESULT AND DISCUSSION}

\section{A. The Motor-manual Tapping Tool}

In this study, the hand-held tapping machine was modified from STIHL FR 3000 weeding machine with a hand-made cutting head (12 cm diameter of gear) (Figure 2). The total weight of this machine was approximately 13 $\mathrm{kg}$ (average). Refreshing work in a tapping face, bark removal activity, was repeated periodically (once per three days). Three times refreshing was followed by resin collecting work (usually once per 10 days tapping period). Thus, the readers can get a broader insight into how the lean manufacturing concept should be applied in a time study analysis.

\section{B. Special Allowances (SA)}

The added-value work element in one work cycle of tapping operation consists of three effective work elements (EF: walking, cleaning 


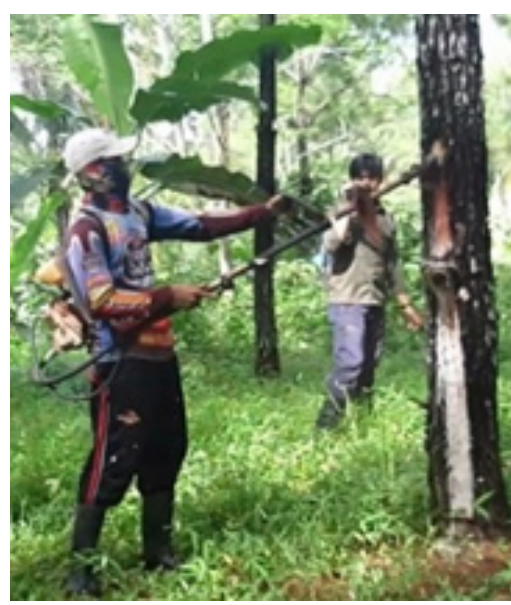

(a)

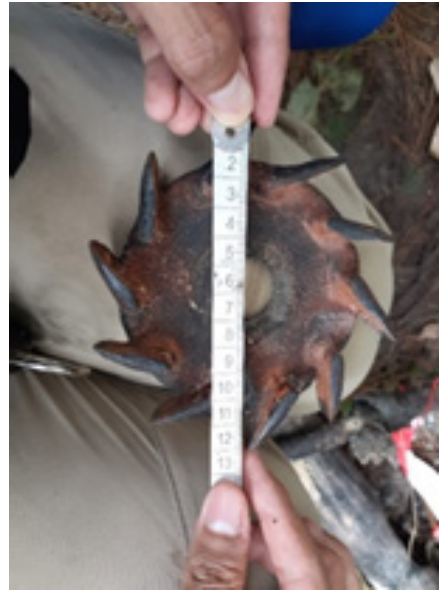

(b)

Figure 3. Tapping a pine tree: (a) hand-held tapping machine, (b) the head cutter's shape

understorey, wounding the tapping face) and two supportive operative elements (SO: reinstalling resin pot and cleaning wood chips). The identified non-value-added work elements were two personal interruption elements (PI: chatting and smoking) and the other two mechanical interruption elements (MI: machine repairing and procuring repairing tools). Further, work preparation and tidying up (after work activity) were defined as work elements that did not meet the supportive work element category. These work elements caused a delay. This delay was unavoidable but yet necessary to effort effective work elements. Tapping work will not go well, if workers do not wear personal protective equipment, starting the machine, and set the machine properly on their back before the operation. Therefore, work preparation and tidying up were categorised into special allowances (Table 2).

\section{Observed time}

The distribution of observed time shows that worker 1 (W1) and worker 2 (W2) spend $40 \%$ and $37 \%$ of their total work time on nonvalue-added work elements, namely repairing machines, chatting, and smoking (Table 3). The activity of repairing machines (caused by improper and/or regular maintenance), chatting, and smoking were intentional delays (Niebel \& Freivalds, 2003), which is no way supported the tapping operation. Thus, these activities were categorised as "waste" (Mayer, Maciel, Baggio, \& Siendenberg, 2015) and were not further calculated (Cury \& Saraiva, 2018). Given that apart from tapping, workers also have other activities to be carried out after tapping, waste activities must be eliminated. Conducting regular maintenance on the tapping machines, stopping or reducing smoking habits, and stopping chatting about unnecessary subjects will reduce waste elements. Regular maintenance will reduce the risk of delay in the middle of the operation. In terms of smoking, apart from time-consuming, this habit is expensive. Yovi and Yamada (2019) revealed that cigarette consumption expenditure could reach up to $17 \%$ of a household's monthly total income.

\section{Basic time}

Preliminary observations and field supervisors' assessment showed that worker 3 (W3, 26 years of work experience) worked normally. Thus this RF was set as 1 . W1 tend to work faster than others $(\mathrm{RF}=1.9)$, while W2 was slower $(\mathrm{RF}=0.75)$. The observed time for the value-added work element (Table 3) was then multiplied by the RF value to obtain the basic time for each work element (Figure 4). The basic time distribution shows that the dominant work element in tapping is walking (EF1) and 
Table 2 The added-value, non-added-value, and special allowances in a work cycle of tapping operation

\begin{tabular}{|c|c|c|}
\hline \multirow{2}{*}{\multicolumn{2}{|c|}{$\begin{array}{l}\text { Work elements } \\
\text { Effective work elements }\end{array}$}} & \multirow[t]{2}{*}{ Descriptions } \\
\hline & & \\
\hline EF1 & Walking & $\begin{array}{l}\text { Walking from the work hut to the work area or walking among } \\
\text { the trees. }\end{array}$ \\
\hline EF2 & Cleaning understory & Clearing of undergrowth. \\
\hline EF3 & Making refreshing wound & $\begin{array}{l}\text { Any activity performed when workers make a wound on the } \\
\text { tapping face. }\end{array}$ \\
\hline \multicolumn{3}{|c|}{ Special allowance (unavoidable delays) } \\
\hline SA1 & Work preparation & $\begin{array}{l}\text { Work preparation activities consisted of wearing PPE (mask } \\
\text { and safety shoes), start the tapping machine, and put on the } \\
\text { machine on their back. This preparatory activity was carried out } \\
\text { in the work hut. }\end{array}$ \\
\hline SA2 & Tidying up & $\begin{array}{l}\text { Turning off the engine, putting off the machine, and taking } \\
\text { out PPE. }\end{array}$ \\
\hline \multicolumn{3}{|c|}{ Supportive operation } \\
\hline SO1 & Reinstalling/relocating resin pot & $\begin{array}{l}\text { This activity was carried out when workers find a resin pot not } \\
\text { correctly positioned to hold resin. }\end{array}$ \\
\hline $\mathrm{SO} 2$ & Cleaning wood chips & $\begin{array}{l}\text { Refreshing work caused by small pieces of wood which get } \\
\text { stuck all over the body. The cleaning of wood chips activity was } \\
\text { carried out when the tappers felt being disturbed by the chips. }\end{array}$ \\
\hline \multicolumn{3}{|c|}{ Personal interruption } \\
\hline PI1 & Chatting & $\begin{array}{l}\text { Chatting was defined as talking about topics with no relation } \\
\text { (directly and indirectly) to work activities. }\end{array}$ \\
\hline PI2 & Smoking & $\begin{array}{l}\text { Smoking was done while resting in the hut after the refreshing } \\
\text { activity. }\end{array}$ \\
\hline \multicolumn{3}{|c|}{ Mechanical interruption } \\
\hline MI1 & Machine repairing & $\begin{array}{l}\text { Machine repair activities consisted of checking the engine's } \\
\text { condition, spark plugs, and repairing the cutter head. }\end{array}$ \\
\hline MI2 & Procuring repairing tools & $\begin{array}{l}\text { This element consisted of taking screwdrivers or spare spark } \\
\text { plugs and a grind to sharpen the cutter. }\end{array}$ \\
\hline
\end{tabular}

Remarks $: \mathrm{EF}=$ effective working element; $\mathrm{SA}=$ special allowances; $\mathrm{SO}=$ supportive operative; $\mathrm{PI}=$ personal interuption; $\mathrm{MI}=$ mechanical interruption

wounding (EF3). The basic time distribution also shows that W3, the standard worker, performed cautious tapping. During tapping, he also removed the dirt and reinstalled the position of the resin pot. Proper pot installation will reduce the chance of spilling resin, saving the volume of resin being harvested.

\section{E. Constant and Variable Allowances}

In this study, allowances were calculated for each work element. The allowance type and its value follow the activity's characteristics and its specific workplace environment (Niebel \& Freivalds, 2003). Tapping activities were often carried out at tapping points exceeding $2.5 \mathrm{~m}$ above the forest floor, causing an exceeding shoulders flexion. The concept of natural Range of Motion (Openshaw \& Taylor, 2006) has classified this shoulder movement as "extreme." Yovi, Takimoto, Ichihara, and Matsubara (2005) state that physiological workload during making refreshing wounds at breast height may burden workers with $51 \%$ VdotO2max, which could be higher in an awkward posture. Awkward postures trigger musculoskeletal stress, cause higher physical work and musculoskeletal disorders (Yovi \& Andriyani, 2019). In addition, the use of a tapping machine in this work may cause unintended noise exposure that triggers psychological stress to the worker 
Table 3. Observed time in motor-manual pine tapping operation

\begin{tabular}{|c|c|c|c|c|c|}
\hline & \multirow{2}{*}{ Work elements } & \multirow{2}{*}{ Work situation } & \multicolumn{3}{|c|}{ Observed time (s) } \\
\hline & & & Worker 1 & Worker 2 & Worker 3 \\
\hline \multicolumn{6}{|c|}{ Effective work elements } \\
\hline EF1 & Walking & $\begin{array}{l}\text { Standing, carrying tapper } \\
\text { machine, exposed by } \\
\text { atmospheric conditions, } \\
\text { exposed by low noise level } \\
\text { (machine idling) }\end{array}$ & 2157 & 1297 & 1999 \\
\hline EF2 & Cleaning understorey & $\begin{array}{l}\text { Standing, carrying tapper } \\
\text { machine, exposed by } \\
\text { atmospheric conditions, } \\
\text { exposed by noise }\end{array}$ & 105 & 14 & 96 \\
\hline EF3 & $\begin{array}{l}\text { Making refreshing } \\
\text { wound }\end{array}$ & $\begin{array}{l}\text { Standing, carrying tapper } \\
\text { machine, exposed by } \\
\text { atmospheric conditions, } \\
\text { exposed by noise }\end{array}$ & 2233 & 1357 & 1321 \\
\hline \multicolumn{6}{|c|}{ Special allowances } \\
\hline \multirow[t]{4}{*}{ SA1 } & Putting on PPE & $\begin{array}{l}\text { Standing, not carrying } \\
\text { tapper machine, } \\
\text { exposed by atmospheric } \\
\text { conditions, not exposed } \\
\text { by noise }\end{array}$ & 17 & 30 & 0 \\
\hline & $\begin{array}{l}\text { Starting the tapper } \\
\text { machine }\end{array}$ & $\begin{array}{l}\text { Bending, not carrying } \\
\text { tapper machine, } \\
\text { exposed by atmospheric } \\
\text { conditions, not exposed } \\
\text { by noise }\end{array}$ & 228 & 15 & 12 \\
\hline & $\begin{array}{l}\text { Put the engine on the } \\
\text { back. }\end{array}$ & $\begin{array}{l}\text { Standing, carrying tapper } \\
\text { machine, exposed by } \\
\text { atmospheric conditions, } \\
\text { exposed by low noise level } \\
\text { (machine idling) }\end{array}$ & 54 & 27 & 32 \\
\hline & Total S1 & & 298 & 72 & 44 \\
\hline \multirow[t]{2}{*}{ SA2 } & Set off tapper machine & $\begin{array}{l}\text { Standing, not carrying } \\
\text { tapper machine, } \\
\text { exposed by atmospheric } \\
\text { conditions, exposed by } \\
\text { low noise level (machine } \\
\text { idling) }\end{array}$ & 42 & 13 & 35 \\
\hline & Putting off PPE & $\begin{array}{l}\text { Bending, not carrying } \\
\text { tapper machine, } \\
\text { exposed by atmospheric } \\
\text { conditions, not exposed } \\
\text { by noise }\end{array}$ & 20 & 21 & 0 \\
\hline SO1 & $\begin{array}{l}\text { Reinstalling/relocate } \\
\text { the resin pot }\end{array}$ & $\begin{array}{l}\text { Mostly bending, } \\
\text { carrying tapper machine, } \\
\text { exposed by atmospheric } \\
\text { conditions, exposed by } \\
\text { low noise level (machine } \\
\text { idling) }\end{array}$ & 53 & 18 & 128 \\
\hline
\end{tabular}


Table 3 Continued

\begin{tabular}{|c|c|c|c|c|c|}
\hline & \multirow{2}{*}{ Work elements } & \multirow{2}{*}{ Work situation } & \multicolumn{3}{|c|}{ Observed time (s) } \\
\hline & & & Worker 1 & Worker 2 & Worker 3 \\
\hline $\mathrm{SO} 2$ & $\begin{array}{l}\text { Cleaning body from } \\
\text { wood chips }\end{array}$ & $\begin{array}{l}\text { Standing, carrying tapper } \\
\text { machine, exposed by } \\
\text { atmospheric conditions, } \\
\text { exposed by low noise level } \\
\text { (machine idling) }\end{array}$ & 84 & 23 & 14 \\
\hline \multicolumn{6}{|c|}{ Personal interruption } \\
\hline PI1 & Chatting & $\begin{array}{l}\text { Sitting, not carrying tapper } \\
\text { machine, exposed by } \\
\text { atmospheric conditions, } \\
\text { not exposed by noise }\end{array}$ & 315 & 33 & 104 \\
\hline PI2 & Smoking & $\begin{array}{l}\text { Sitting, not carrying tapper } \\
\text { machine, exposed by } \\
\text { atmospheric conditions, } \\
\text { not exposed by noise }\end{array}$ & 1378 & 1578 & 0 \\
\hline \multicolumn{6}{|c|}{ Mechanical interruption } \\
\hline MI1 & $\begin{array}{l}\text { Maintaining the } \\
\text { machine }\end{array}$ & $\begin{array}{l}\text { Sitting, not carrying tapper } \\
\text { machine, exposed by } \\
\text { atmospheric conditions, } \\
\text { not exposed by noise }\end{array}$ & 1428 & 18 & 47 \\
\hline MI2 & $\begin{array}{l}\text { Taking things from the } \\
\text { work hut }\end{array}$ & $\begin{array}{l}\text { Standing, not carrying } \\
\text { tapper machine, } \\
\text { exposed by atmospheric } \\
\text { conditions, not exposed } \\
\text { by noise }\end{array}$ & 257 & 18 & 12 \\
\hline Total cyc & le time & & 8371 & 4462 & 3800 \\
\hline
\end{tabular}

Remarks: $\mathrm{EF}=$ effective work element; $\mathrm{SA}=$ special allowances; $\mathrm{SO}=$ supportive operative; $\mathrm{PI}=$ personal interruption; $\mathrm{MI}=$ mechanical interruption

(Ising \& Kruppa, 2004). Another concern that should also be addressed is the effects of excessive atmospheric heat, as has been verified by Krishnamurty, Ramalingan, Perumal, Kamalakanman, Chinnadurai, and Shanmugam (2017) and Notley, Meade, Souza, McGarr, and Kenny (2018) as this outdoor work is carried out in Indonesia.

Given that humans have limitations on physical, physiological, and psychological mechanisms (Kroemer \& Grandjean, 1997), constant fatigue (personal needs and basic fatigue) allowances were added to all value-added work elements, both for effective and supportive work elements. The constant allowance was set at $9 \%$. According to the work characteristics, the variable fatigue allowances taken into account in this study were standing, abnormal posture, muscular energy, atmospheric conditions, and noise. In contrast, other variable relaxation allowances, i.e., illumination level, visual strain, mental strain, monotony, and repetitiveness, were excluded from the calculation (Table 4). Postural relaxation allowances for almost all elements were set at $2 \%$ because it was carried out in a standing position. Fatigue allowance for muscular energy is based on whether or not the load (machine) is carried when completing an element (ILO, 1979) (Table 1). In the case of relaxation allowances caused by atmospheric conditions, the amount of energy expenditure for each work element was calculated based on Yovi, Takimoto, Ichihara, and Matsubara (2005). For EF1, EF2, EF3, and SA13, the amount of physical workload was equivalent to $264.8 \mathrm{kcal} / \mathrm{h}$, while the amount of energy 


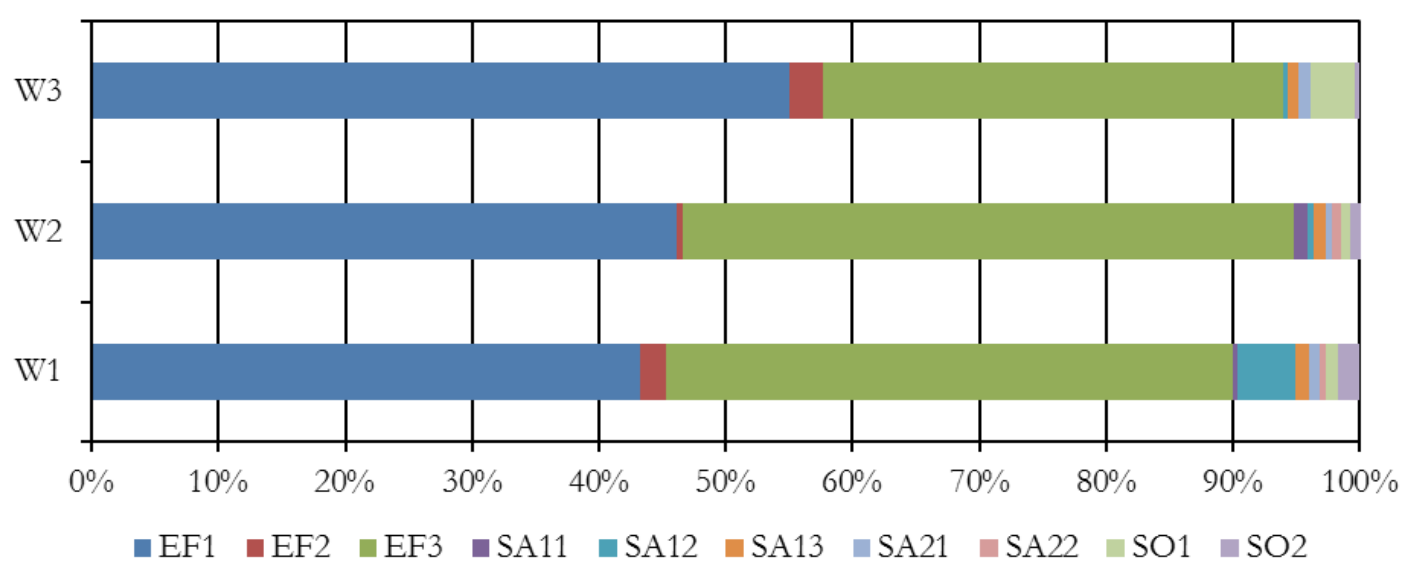

Figure 4. Basic time distribution of added-value and operative work element in motor-manual pine tapping operation

Remarks: EF1 = walking; EF2 = cleaning understorey; EF3 = making refreshing wound; SA11 = putting on PPE; SA12 = starting the tapping machine; SA13 = putting engine on the back; SA21 = putting off tapper machine; SA22 = putting off PPE; SO1 $=$ reinstalling the resin pot; SO2 = cleaning wood chips

expenditure on the rest activities was considered to be $93.8 \mathrm{kcal} / \mathrm{h}$. Rest allowance calculations for atmospheric conditions was $12.5 \%$ for $\mathrm{WGBT}=86^{\circ} \mathrm{F}$ and $\mathrm{W}=264.8 \mathrm{kcal} / \mathrm{h}$, and $1 \%$ for $\mathrm{WGBT}=86^{\circ} \mathrm{F}$ and $\mathrm{W}=93.8 \mathrm{kcal} / \mathrm{h}$. For noise factor, a high rotational speed engine can produce $94-96 \mathrm{~dB}(\mathrm{~A})$ of noise, which according to OSHA-Permissible Noise Level, its permissible time is four hours. However, since the actual workday duration was less than two hours, $5 \%$ of the allowance was applied for working elements exposed by loud noise, and 0\% applied for idling machines (considered as continuous-low level noise) (ILO, 1979).

\section{F. Standard Time}

Lan et al. (2009) underline the importance of work measurement in determining reasonable working time quota. Measuring standard time value is beneficial for both employers and tapping workers because pine resin harvesting is mostly considered a side economic activity (Yovi \& Amanda, 2019). The standard time required to complete the tapping operation per tree was obtained by multiplying the standard time by its allowances multiplier (Table 5) (Niebel \& Freivalds, 2003).
The total time required to complete tapping per tree (with two or three tapping faces) was 48-49 seconds. It means that by putting aside the house-workout travel time, tapping a 20 years pine stand with 150 trees is expected to be completed within approximately 2 hours of effective work. This verifies that hand-held machines offer far higher work productivity than conventional tapping tools. According to Yovi et al. (2005), the duration of initial observations of tapping productivity using conventional tapping tools was about 81 seconds per tree. It means that for the same number of trees, a worker needs 3.4 hours, which is 1.7 times longer. The average number of trees tapped per day by a worker who does tapping using the conventional tool only reaches $100-120$ trees (or less) per day (Yovi \& Amanda, 2019).

This study verified that the tapping operation, due to its uncontrollable work environment factors (Maughan, Otani, \& Watson, 2012; Notley, Meade, D’Souza, McGarr, \& Kenny, 2018), should be carried out in the morning. If tapping is carried out from 7 AM, the whole operation will be finished before $10 \mathrm{AM}$. This time range is the proper working duration to avoid excessive heat. This 
Table 4. Basic time and allowances of added-value work elements in motor-manual pine tapping operation

\begin{tabular}{|c|c|c|c|c|c|c|c|c|c|}
\hline \multirow[b]{3}{*}{ WE } & \multirow{2}{*}{\multicolumn{3}{|c|}{ Basic time (s) }} & \multicolumn{6}{|c|}{ Allowances (\%) } \\
\hline & & & & \multicolumn{2}{|c|}{$\begin{array}{l}\text { Constant } \\
\text { allowances }\end{array}$} & \multicolumn{4}{|c|}{ Variable fatigue allowances } \\
\hline & W1 & W2 & W3 & $\begin{array}{l}\text { Personal } \\
\text { needs }\end{array}$ & $\begin{array}{c}\text { Basic } \\
\text { fatigue }\end{array}$ & $\begin{array}{l}\text { Abnormal } \\
\text { posture }\end{array}$ & $\begin{array}{c}\text { Use of force/ } \\
\text { muscular } \\
\text { energy }\end{array}$ & $\begin{array}{l}\text { Atmospheric } \\
\text { conditions }\end{array}$ & Noise \\
\hline EF1 & 4098 & 973 & 1999 & 5 & 4 & 2 & 5 & 12.5 & 0 \\
\hline EF2 & 200 & 11 & 96 & 5 & 4 & 2 & 5 & 12.5 & 5 \\
\hline EF3 & 4243 & 1018 & 1321 & 5 & 4 & 2 & 5 & 12.5 & 5 \\
\hline SA11 & 32 & 23 & 0 & 5 & 4 & 2 & 0 & 1 & 0 \\
\hline SA12 & 433 & 11 & 12 & 5 & 4 & 2 & 0 & 1 & 0 \\
\hline SA13 & 103 & 20 & 32 & 5 & 4 & 2 & 5 & 12.5 & 0 \\
\hline SA21 & 80 & 10 & 35 & 5 & 4 & 2 & 0 & 1 & 0 \\
\hline SA22 & 38 & 16 & 0 & 5 & 4 & 2 & 0 & 1 & 0 \\
\hline SO1 & 101 & 14 & 128 & 5 & 4 & 2 & 5 & 1 & 0 \\
\hline SO2 & 160 & 17 & 14 & 5 & 4 & 2 & 5 & 1 & 0 \\
\hline
\end{tabular}

Remarks: WE = work element; W1 = worker 1; W2 = worker 2; W3 = worker 3; EF1 = walking; EF2 = cleaning understorey; $\mathrm{EF3}=$ making refreshing wound; SA11 = putting on PPE; SA12 = starting the tapping machine; SA13 = putting engine on the back; SA21 = putting off tapper machine; SA22 = putting off PPE; $\mathrm{SO} 1=$ reinstalled the resin pot; $\mathrm{SO} 2=$ cleaning wood chips

Table 5. Multiplier and standard time of added-value work elements in motor-manual pine tapping operation

\begin{tabular}{|c|c|c|c|c|c|}
\hline \multirow{2}{*}{ Work elements } & \multirow{2}{*}{$\begin{array}{c}\text { Total allowances } \\
(\%)\end{array}$} & \multirow{2}{*}{ Multiplier } & \multicolumn{3}{|c|}{ Standard time (s) } \\
\hline & & & W1 & W2 & W3 \\
\hline EF1 & 28.5 & 1.285 & 5266 & 1250 & 2569 \\
\hline EF2 & 33.5 & 1.335 & 256 & 12 & 123 \\
\hline EF3 & 33.5 & 1.335 & 5452 & 1308 & 1697 \\
\hline SA11 & 12 & 1.12 & 42 & 29 & 0 \\
\hline SA12 & 12 & 1.12 & 557 & 14 & 15 \\
\hline SA13 & 28.5 & 1.285 & 132 & 26 & 41 \\
\hline SA21 & 12 & 1.12 & 103 & 13 & 45 \\
\hline SA22 & 12 & 1.12 & 49 & 20 & 0 \\
\hline SO1 & 17 & 1.17 & 129 & 17 & 164 \\
\hline \multirow[t]{4}{*}{$\mathrm{SO} 2$} & 17 & 1.17 & 205 & 22 & 18 \\
\hline & \multicolumn{2}{|c|}{ Total standard time per cycle (s) } & 12190 & 2713 & 4674 \\
\hline & \multicolumn{2}{|c|}{ Total tapped trees } & 253 & 57 & 95 \\
\hline & \multicolumn{2}{|c|}{ Duration per tree $(\mathrm{s})$} & 48 & 48 & 49 \\
\hline
\end{tabular}

Remarks: W1 = worker 1; W2 = worker 2; W3 = worker 3; EF1 = walking; EF2 = cleaning understorey; EF3 = making refreshing wound; SA11 = putting on PPE; SA12 = starting the tapping machine; SA13 = putting engine on the back; SA21 = putting off tapper machine; SA22 = putting off PPE; SO1 = reinstalled the resin pot; $\mathrm{SO} 2$ = cleaning wood chips

information can also be used to organise the work shift of a workers' group who share the same machine. For plantation owners, this standard time information is useful guidance in managing tapping operation, e.g., regulate the optimum tapping area for each worker according to management objectives (the distribution of tapping income, characteristics of local economics, or the availability of workers). Given that, globally, pine resin is 
one of the potential Indonesian commodities (BPS, 2018), the use of machine tools should be considered as one promising alternative strategy in improving pine resin production.

However, operating (manuvering and controlling) this machine may require a higher physical workload as noted by the study of Hansen, Rasmussen, Kyed, Nielsen, and Andersen (2012) and vibration-noise exposure as mentioned by Ljungberg, Neely, and Lunstrom (2004), not to mention the environmental factors of the work. A wellknown environmental factor that negatively influences human physiology is the heat at the workplace, as was noted by Krishnamurthy et al. (2017). Before this study, Maughen et al. (2012) noted that relative humidity is a potential environmental factor that should also be considered and may cause severe effects in human with prolonged exercise capacity. In relating to the climate change issue, Otani et al. (2016) also underline the negative effect of solar radiation on human health.

This study revealed that two major work elements dominate refreshing work: walking (while carrying the $13 \mathrm{~kg}$ tapping machine) and wounding a tapping face. "Walking" in this study refers to "carrying" (Table 2), a part of manual material handling because, during tapping, the machine was set on the back of the worker. Walking is one major work element; therefore, the issue on the excessive low back (L5/S1 lumbosacral disk) compression force should be further considered (Hasegawa, Katsuhira, Oka, Fujii, \& Matsudaira, 2018).

This human health-work environment issue should get serious attention as humans are complex creatures with limitations in the physical, physiological, and mental dimensions that limit their ability to carry out work (Kroemer \& Grandjean, 1997). Therefore, more in-depth work analysis on physiological and psychological costs (Kroemer \& Grandjean, 1997) during motor-manual tapping should be carried out in the next research stage. The energy expenditure, the effect of vibration noise, postural analysis (including the psychophysical analysis), and the risk perception (Schmidt, 2004) are other ergonomic aspects that need to be analysed. This research will provide useful, necessary information in determining the optimum tapping management for the sake of worker's well-being, which in the long run will improve the company's overall performance.

\section{CONCLUSION}

The concept of lean manufacturing that considers the relationship of work elements to work productivity has offered an objective approach to work productivity calculations. In this time study analysis, the lean manufacturing concept shows that personal interruption and machine interruption are significantly time-consuming and have no contribution to effective work. Therefore, periodic machine maintenance and chatting-smoking during tapping work should be classified as nonvalue-added work elements. These non-valueadded work elements must be reduced or fully eliminated to increase work productivity. Other work elements do not directly support tapping activities, but their existence is still required so that tapping operations can be carried out. This supportive work element needs to be categorised as value-added work elements but should be minimised. This study identifies reinstalling resin pots and cleaning wood chips as supportive work elements, while work preparation and tidying up as unavoidable delays existed in pine tapping activities. The variable fatigue allowances (that accommodates the human's limitation) that should be applied in standard time calculation of tapping operation are standing, abnormal posture, use of force/ muscular energy, atmospheric conditions, and noise. The multiplier (allowances factors) for tapping operation using the hand-held tapping machine ranges from 1.12-1.34, depending on the specific work characteristics per work element. This study shows that a handheld tapping machine offers higher work productivity (1.7 times higher) than the tapping by using conventional tools. However, there is also a need to carry out the physical workload, 
postural analysis, and risk perception analysis on motor-manual tapping. A continuously improved tapping process can be formulated not only for efficient operation but also for the workers' well-being.

\section{ACKNOWLEDGEMENT}

We thank our colleagues from IPB University and Perum Perhutani for their valuable insight and expertise that greatly assisted the research.

\section{REFERENCES}

Borino, F. (2018). Better work. Retrieved from https://betterwork.org/portfolio/ discussion-paper-28-piece-rate-pay-andworking-conditions-in-the-export-garmentsector/ on November 30, 2020.

BPS. (2018). Beranda: Kehutanan. Retrieved from https://www.bps.go.id/subject/60/ kehutanan.html\#subjekViewTab4 on September 18, 2020.

BPS. (2020). Beranda: Kehutanan. Retrieved from https://www.bps.go.id/subject/60/ kehutanan.html\#subjekViewTab4 on September 18, 2020.

Cury, P., \& Saraiva, J. (2018). Time and motion study applied to a production line of organic lenses in Manaus Industrial Hub. Gestão da Produção, Operações e Sistemas, 901-915. doi://dx.doi. org/10.1590/0104-530x2881-18.

Davis, M. (2016). Pay matters: The piece rate and health in the developing world. Annals of Global Health, 82(5), 858-865. doi:// 10.1016/j.aogh.2016.05.005.

Garg, A., Chaffin, D., \& Herrin, G. (1978). Prediction of metabolic rates for manual materials handling jobs. American Industrial Hygiene Association Journal, 39(12), 661-674.

Hansen, C., Rasmussen, K., Kyed, M., Nielsen, K., \& Andersen, J. (2012). Physical and psychosocial work environment factors and their association with health outcomes in Danish ambulance personnel - A crosssectional study. BMC Public Health, 12(1), 534. doi: 10.1186/1471-2458-12-534.

Hart, R. (2016). The rise and fall of piecework. Bonn: IZA World of Labor.
Hasegawa, T., Katsuhira, J., Oka, H., Fujii, H., \& Matsudaira, K. (2018). Association of low back load with low back pain during static standing. PLoS One, 13(12), e0208877. doi:// 10.1371/journal.pone.0208877.

ILO. (1979). Introduction of work study. Geneva: Impression Couleurs Weber.

Ising, H., \& Kruppa, B. (2004). Health effects caused by noise: Evidence in the literature from the past 25 years. Noise Health, 6(22), 5-13. Retrieved from https://pubmed.ncbi. nlm.nih.gov/15070524/ on the 1st December 2020.

Krishnamurty, M., Ramalingan, P., Perumal, K., Kamalakannan, L., Chinnadurai, J., \& Shanmugam, R. (2017). Occupational heat stress impacts on health and productivity in steel industry in Southern India. Safety and Health at Work, 8(1), 99-104. doi:// 10.1016/j. shaw.2016.08.005.

Kroemer, K., \& Grandjean, E. (1997). Fitting the task to the human. $5^{\text {th }}$ Edition. Bristol: Taylor \& Francis.

Lan, S., Wang, X., \& Ma, L. (2009). Optimisation of assembly line based on work study. The $16^{\text {th }}$ International Conference on Industrial Engineering and Engineering Management (pp. 813-816). Beijing: Industrial Engineering and Engineering Management. doi:// 10.1109/ ICIEEM.2009.5344476.

Ljungberg, J., Neely, G., \& Lunstrom, R. (2004). Cognitive performance and subjective experience during combined exposures to whole-body vibration and noise. International Archives of Occupational and Environmental Health, 217-221. doi:// 10.1007/s00420-0030497-7.

Maughan, R., Otani, H., \& Watson, P. (2012). Influence of relative humidity on prolonged exercise capacity in a warm environment. Europian Journal of Applied Physiology, 112(6), 2313-2321. doi:// 10.1007/s00421-011-22067.

Mayer, P., Maciel, A., Baggio, D., \& Siendenberg, D. (2015). Implementation of methodology for analysing the added value in metallurgical industry of custom products. Gestão da Produção, Operações e Sistemas, 10(1), 177-195. doi:// 10.15675/gepros.v10i1.1178.

Niebel, B., \& Freivalds, A. (2003). Methods, standards, and work design. Boston: McGraw-Hill. 
NIOSH. (1989). Criteria for a recommended standard for occupational exposure to hot environments. Cincinnati: National Institute for Occupational Safety and Health.

Notley, S., Meade, R., D’Souza, A., McGarr, G., \& Kenny, G. (2018). Cumulative effects of successive workdays in the heat on thermoregulatory function in the aging worker. Temperature, 5(4), 293-295. doi:// 10.1080/23328940.2018.1512830.

Openshaw, S., \& Taylor, E. (2006). Ergonomics and design - A reference guide. Iowa: Allsteel Inc.

OSHA. (1983). Occupational noise exposure: Hearing conservation amendment, Federal Register 48. Washington, DC: Occupational Safety and Health Administration.

Otani, H., Kaya, M., Tamaki, A., Watson, P., \& Maughan, R. (2016). Effects of solar radiation on endurance exercise capacity in a hot environment. European Journal of Applied Physiology, 116(4), 769-779. doi: 10.1007/ s00421-016-3335-9.

Perhutani. (2020). Tentang Perhutani: Struktur organisasi. Retrieved from Perhutani: https:/ / perhutani.co.id/, on September 18, 2020.

Schmidt, M. (2004). Loss of agro-biodiversity in Vavilov centers, with a special focus on the risk of genetically modified organism (GMOs). (Doctoral dissertation). Retrieved from http:// www.markusschmidt.eu/pdf/Intro_risk_ perception_Schmidt.pdf. on September 18, 2020.
TrendEconomy. (2019). Annual international trade statistics by country: Indonesia. Retrieved from https://trendeconomy. com $/$ data $/$ h2?commodity $=3806,380690$ \&reporter=Indonesia\&trade_flow $=$ Export, Import\&partner $=$ World \&indicator $=$ NW, TQ, TV\&time_period $=2019$ on September 18, 2020.

Womack, J., \& Jones, D. (2003). Lean thinking. New York: Free Press.

Yovi, E., \& Amanda, N. (2019). Ergonomic analysis of traditional pine oleoresin tapping: Musculoskeletal disorders, cumulative fatigue, and job satisfaction. Jurnal Sylva Lestari, 283296. doi:// 10.23960/js138283-296.

Yovi, E., \& Andriyani, L. (2019). Analisis postur kerja dalam operasi pemanenan kayu: Pemuatan log secara manual. Jurnal Ilmiah Teknik Industri, 18(2), 170-182. doi: 10.23917/jiti.v418i2.8727.

Yovi, E., \& Yamada, Y. (2019). Addressing occupational ergonomics issues in Indonesian forestry: laborers, operators or equivalent workers. Croatian Journal of Forest Engineering, 49(2), 351-363. doi: 10.5552/crojfe.2019.558.

Yovi, E., Takimoto, Y., Ichihara, K., \& Matsubara, C. (2005). Factors affecting workload and work efficiency in pine resin harvesting operation in Java's plantation forest. Journal of the Japan Forest Engineering Society, 20(3), 141-150 